\title{
Determining Ploidy Level and Nuclear DNA Content in Rubus by Flow Cytometry
}

\author{
Rengong Meng \\ Department of Horticulture, Oregon State University, Corvallis, OR 97330 \\ Chad Finn \\ U.S.Department of Agriculture-Agricultural Research Service, HCRL, Northwest Center for Small Fruit \\ Research, 3420 NW Orchard Avenue, Corvallis, OR 97330
}

\begin{abstract}
AdDitional INDEX WORDS. propidium iodide (PI), blackberry, raspberry, genome size
Abstract. Nuclear DNA flow cytometry was used to differentiate ploidy level and determine nuclear DNA content in Rubus. Nuclei suspensions were prepared from leaf discs of young leaves following published protocols with modifications. DNA was stained with propidium iodide. Measurement of fluorescence of 40 genotypes, whose published ploidy ranged from diploid to dodecaploid, indicated that fluorescence increased with an increase in chromosome number. Ploidy level accounted for $99 \%$ of the variation in fluorescence intensity $\left(r^{2}=0.99\right)$ and variation among ploidy levels was much higher than within ploidy levels. This protocol was used successfully for genotypes representing eight different Rubus subgenera. Rubus ursinus Cham. and Schldl., a native blackberry species in the Pacific Northwest, which has been reported to have $6 x, 8 x, 9 x, 10 x, 11 x$, and $12 x$ forms, was extensively tested. Genotypes of $R$. ursinus were predominantly $12 x$, but $6 x, 7 x, 8 x, 9 x, 11 x$, and 13x forms were found as well. Attempts to confirm the 13x estimates with manual counts were unsuccessful. Ploidy level of 103 genotypes in the USDA-ARS breeding program was determined by flow cytometry. Flow cytometry confirmed that genotypes from crosses among $7 x$ and $4 x$ parents had chromosome numbers that must be the result of nonreduced gametes. This technique was effective in differentiating chromosome numbers differing by 1x, but was not able to differentiate aneuploids. Nuclear DNA contents of 21 diploid Rubus species from five subgenera were determined by flow cytometry. Idaeobatus, Chamaebatus, and Anaplobatus were significantly lower in DNA content than those of Rubus and Cylactis. In the Rubus subgenus, $R$. hispidus and $R$. canadensis had the lowest DNA content and $R$. sanctus had the highest DNA content, 0.59 and $0.75 \mathrm{pg}$, respectively. Idaeobatus had greater variation in DNA content among diploid species than the Rubus subgenus, with the highest being from $R$. ellipticus $(0.69 \mathrm{pg})$ and lowest from $R$. illecebrosus (0.47 pg).
\end{abstract}

Rubus is a large genus that includes an estimated 900 to 1000 species that are widely distributed in various ecosystems (Thompson, 1997). A number of commercial crops are members of this genus including red and black raspberries ( $R$. idaeus $\mathrm{L}$. and $R$. occidentalis $\mathrm{L}$.) and blackberries (Rubus sp. L.). The naturally occurring range of chromosome numbers in Rubus species is from $2 \mathrm{n}=2 \mathrm{x}=14$, the diploid state, to $2 \mathrm{n}=14 \mathrm{x}=98$ or possibly $2 \mathrm{n}=18 \mathrm{x}=126$, including odd-ploids and aneuploids (Moore, 1984; Thompson, 1995a). Rubus has 12 subgenera but the species and cultivars used in blackberry and raspberry breeding have largely been from the Rubus or Idaeobatus subgenera, respectively. The Rubus subgenera range from diploids to dodecaploids (Moore, 1984). Presumably, the present day species and cultivars have arisen primarily from the intercrossing of diploid species and occasionally polyploid species (Jennings, 1988). Genotypes representing many different Rubus ploidy levels have been used in blackberry breeding and released as cultivars. Heteroploid crosses are often used to introduce desirable genes from wild species or from elite material of different species or crop types, and can usually generate progenies with varying ploidy levels. Factors such as spontaneous doubling of chromosomes at an early stage of development or the union of a nonreduced gamete (produced by nonreduction of sporocytes during meiosis or reduction of polyploid premeiotic cells that appear nonreduced) with a reduced gamete, both of which are common in Rubus,

Received for publication 2 Oct. 2001. Accepted for publication 14 May 2002. We thank Corwin Willard (Oregon State University) for his instruction in the use of the flow cytometer; Kathiravetpilla Arumuganathan (University of Nebraska) and Maxine Thompson (Corvallis, Ore.) for their helpful advice in the early stages of this work and the USDA-ARS National Clonal Germplasm Repository (Corvallis, Ore.) for providing plant material. makes the results of heteroploid crosses unpredictable (Thompson, 1997). Fertility is often poor if the hybrid is triploid, pentaploid, or an aneuploid with a chromosome number less than hexaploid. At higher ploidy levels, the odd euploid and aneuploid genotypes may be completely fertile (Lawrence, 1986; Waldo, 1950).

In blackberry and raspberry breeding programs, knowing the ploidy level of Rubus genotypes is essential to predict crossing success and parental combinations that might produce problematic progenies. For germplasm enhancement, ploidy level can also serve as a valuable distinguishing taxonomic trait when collections of Rubus are evaluated (Thompson, 1995a, 1995b).

In the Pacific Northwest, the native $R$. ursinus Cham. \& Schldl. is widely distributed and has been a valuable genetic resource for developing trailing blackberry cultivars (Finn et al., 1997). Rubus ursinus has a known ploidy level range from hexaploid to dodecaploid except for septaploid (Brown, 1943). In 1993, R. ursinus was collected from throughout the Pacific Northwest and established in a common garden in Corvallis, Ore. (Anderson and Finn, 1996). These populations were evaluated for horticultural and taxonomic characteristics and superior individuals were identified. To incorporate this material most effectively into erect, semierect and trailing blackberry breeding germplasm, it would be useful to know the ploidy level of the selected genotypes.

Successful chromosome counts have been made on at least 387 Rubus species, $\approx 40 \%$ of the known species in the genus, and 90 cultivars and selections (Thompson, 1995a, 1995b, 1997). Ploidy level in Rubus genotypes has usually been determined by chromosome counts in meristematic tissues, such as root or shoot tips, or pollen mother cells. However, these approaches can be 
limited by the availability of plant tissues in the appropriate state and by the amount of labor required for every sample. These traditional approaches are not practical for the large number of genotypes in a breeding program.

Flow cytometry, with its ability to measure nuclear DNA content rapidly, accurately and conveniently, is increasingly the preferred method for determination of ploidy level in plants (Bennett and Leitch, 1995; Galbraith et al., 1983). Arumuganathan and Earle (1991) established a protocol for nuclear DNA measurement, and thus for ploidy level determination, for over 100 important plant species. DNA contents of only two Rubus species, $R$. idaeus L. (Arumuganathan and Earle, 1991; Bennett and Leitch, 1995) and $R$. odoratus L. (Bennett and Leitch, 1995), have been examined. The genome sizes of more genotypes must be determined if efforts will be undertaken to construct genomic libraries and detect cloned genes in these genotypes because an accurate estimation of genome size is helpful to estimate the number of clones needed to create a species gene library (Bennett and Leitch, 1995).

Other than our preliminary work (Meng and Finn, 1999), there has been no published work on the use of flow cytometry in Rubus. The primary objective of this study was to develop a rapid, inexpensive and routine methodology to determine nuclear DNA content and ploidy level by flow cytometry. This will allow Rubus breeders to plan crosses and select hybrids.

Table 1. Nuclear DNA flow cytometry measurement of fluorescence intensity of propidium iodide-stained nuclei from Rubus cultivars and species of varying ploidy levels.

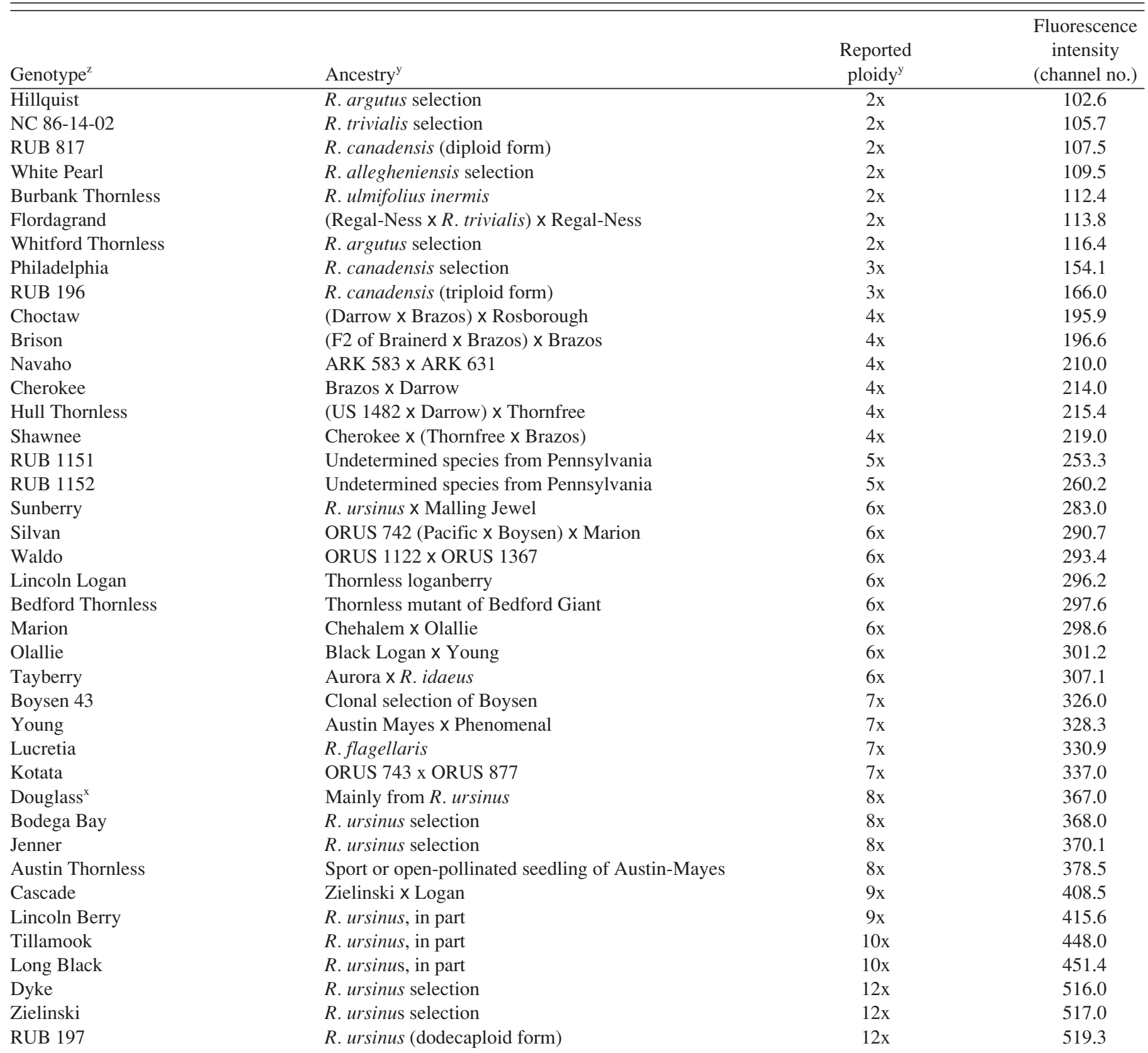

${ }^{\mathrm{z}}$ RUB indicates a USDA-ARS National Clonal Germplasm Repository accession; NC, ARK and ORUS are selections from the North Carolina State University, University of Arkansas and the USDA-ARS/Oregon State University breeding programs, respectively.

${ }^{y}$ As reported by Thompson (1995a, 1995b, 1997)

'Released as 'Black Douglass', patented as 'Douglass'. 


\section{Materials and Methods}

Plant material. Five different sets of plant material were analyzed using flow cytometry. The first group represented the Rubus genotypes with known ploidy levels as determined by Thompson (1995a, 1995b) (Table 1). These were available within our breeding program or at the USDA-ARS National Clonal Germplasm Repository (NCGR), Corvallis. Leaf samples from 40 genotypes were collected and tested using flow cytometry to determine the relationship between chromosome number and fluorescence intensity (Table 1).

The second group was chosen to determine whether this technique would work across the broad range of Rubus subgenera. Thirty genotypes were chosen that represented eight subgenera, had known ploidy numbers (Thompson, 1995b), and were available (Table 2).

To characterize the collection of $R$. ursinus from our germplasm development and breeding program, the third group consisted of a broad sampling of this species (Finn and Martin, 1996). Leaf samples from at least two genotypes in each of 42 R. ursinus populations were analyzed with flow cytometry to determine their ploidy level using the $95 \%$ prediction interval of fluorescence of the regression line obtained previously from the 40 Rubus genotypes with known ploidy levels.

The fourth group consisted of 103 genotypes that were of interest to our breeding or germplasm enhancement program. These include species materials, advanced selections and cultivars from the USDA-ARS and other breeding programs (Table 3).

A final group of 21 diploid Rubus species from five subgenera were analyzed to determine their nuclear DNA content (Table 4). Each genotype was run three times. We would have preferred to analyze more species in the case of subgenera Chamaebatus and Cylactis, but $R$. nivalis is the only diploid species in subgenus Chamaebatus, and $R$. lasiococcus is the only one of the five diploid Cylactis species that was available to us.

NuClei ISOLATION. The protocol for isolating nuclei was adapted from that of Arumuganathan and Earle (1991). $\mathrm{A} \mathrm{MgSO}_{4}$ buffer stock solution, which was composed of $10 \mathrm{~mm} \mathrm{MgSO}_{4}, 50$ mм KCl, and 5 mм HEPES, $\mathrm{pH}$ of 8.0, and a $10 \%$ Triton X-100 $(\mathrm{w} / \mathrm{v})$ stock solution were prepared. A chopping buffer to extract and stabilize nuclei was made based on the $\mathrm{MgSO}_{4}$ buffer with the addition of $20 \mathrm{~g} \cdot \mathrm{L}^{-1} \mathrm{PVP}-10,1 \mathrm{~g} \cdot \mathrm{L}^{-1}$ dithiothreitol, and $28 \mathrm{~mL} \cdot \mathrm{L}^{-1}$ Triton X-100 stock.

About $40 \mathrm{mg}$ of actively-growing Rubus leaves, which had been washed to remove soil, chemicals and other organisms that might react with the chemicals and alter the results, was weighed and placed in a $60-\mathrm{mm}$ plastic petri dish. Preliminary experiments had found that young leaves gave much better resolution than old leaves. Chopping buffer $(1 \mathrm{~mL})$ was added and the petri dish was put on ice. The tissue was chopped, $\approx 100$ chops per sample, with

Table 2. Nuclear DNA flow cytometry measurement of fluorescence intensity of propidium iodide-stained nuclei from Rubus species in eight subgenera.

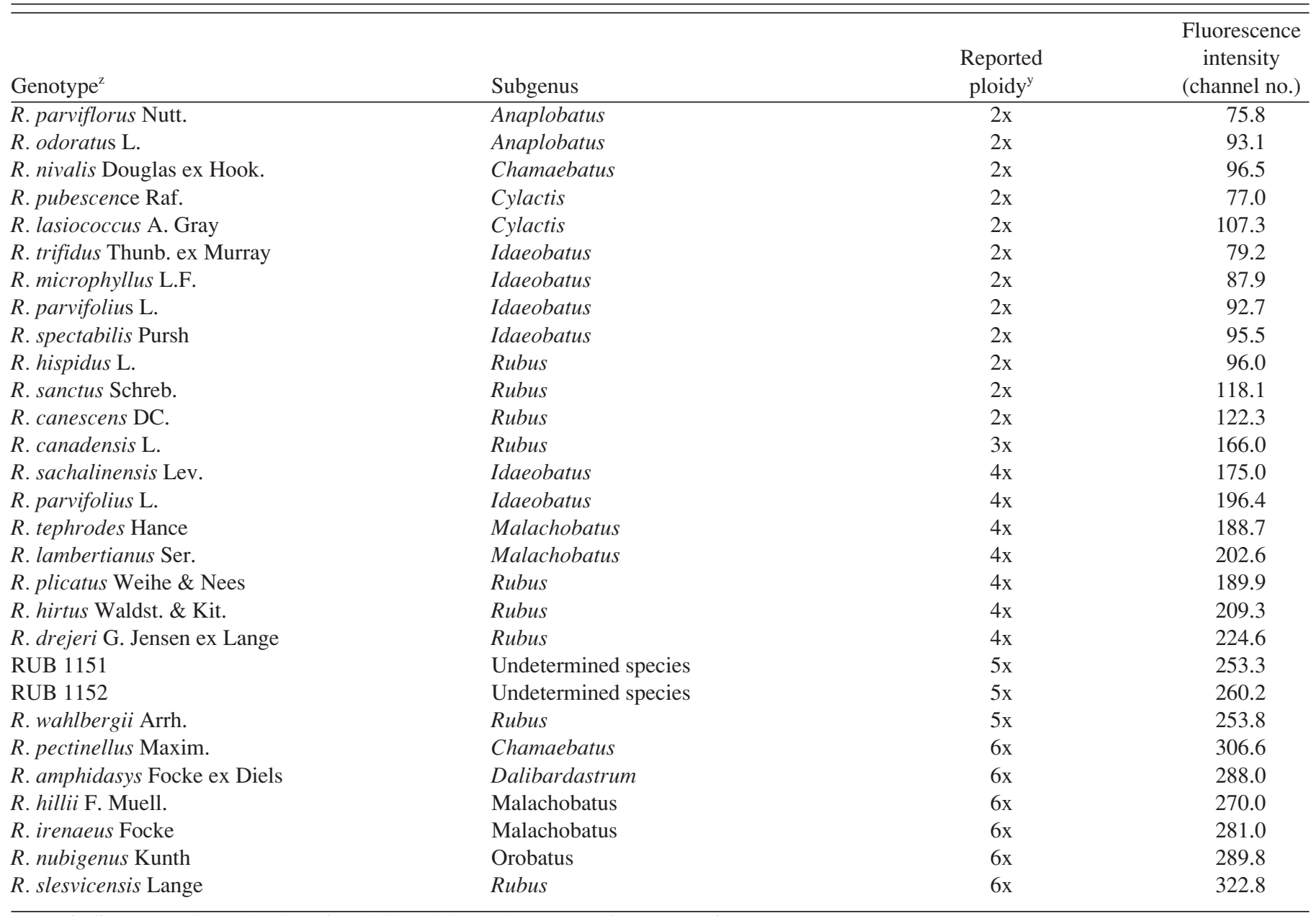

${ }^{\mathrm{z}}$ RUB indicates a USDA-ARS National Clonal Germplasm Repository accession.

y As reported by Thompson (1995a, 1995b, 1997) 
Table 3. Nuclear DNA flow cytometry measurement of fluorescence intensity of propidium iodide-stained nuclei, putative ploidy and parents of 88 USDA-ARS selections and 15 other genotypes within the breeding program.

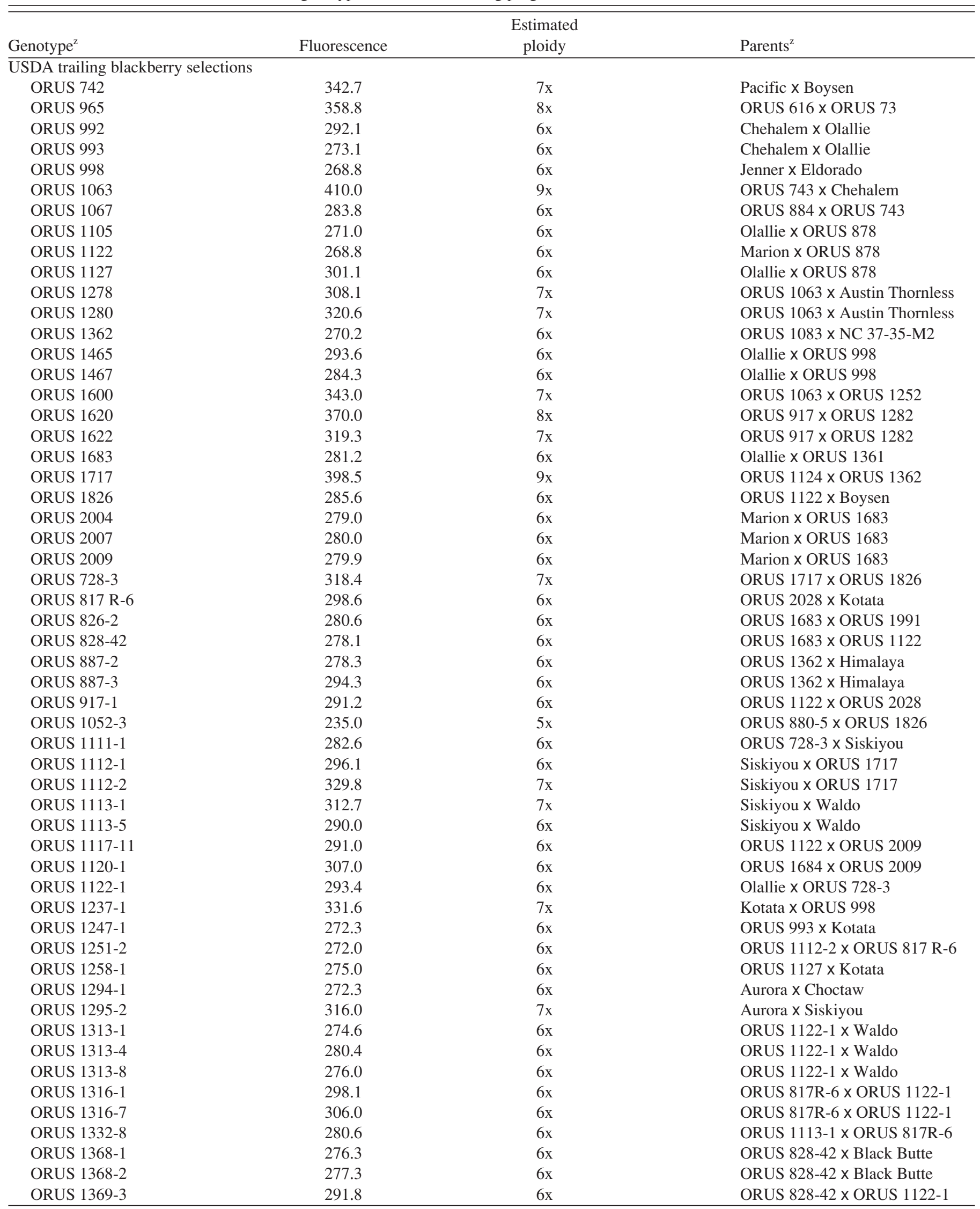




\begin{tabular}{|c|c|c|c|}
\hline Genotype $^{z}$ & Fluorescence & $\begin{array}{l}\text { Estimated } \\
\text { ploidy }\end{array}$ & Parents $^{\mathrm{z}}$ \\
\hline ORUS $1378-2$ & 275.1 & $6 x$ & ORUS $1111-1$ x ORUS 1122-1 \\
\hline ORUS 1380-1 & 400.9 & $9 \mathrm{x}$ & ORUS $1117-11$ x ORUS $1122-1$ \\
\hline ORUS 1382-1 & 280.9 & $6 \mathrm{x}$ & ORUS $1117-11$ x ORUS $728-3$ \\
\hline ORUS 1382-2 & 343.4 & $7 \mathrm{x}$ & ORUS $1117-11 \times$ ORUS $728-3$ \\
\hline ORUS 1392-1 & 204.0 & $4 \mathrm{x}$ & Illini Hardy x Chester Thornless \\
\hline ORUS 1393-1 & 253.0 & $5 \mathrm{x}$ & Navaho x ORUS 1122-1 \\
\hline ORUS 1393-2 & 250.0 & $5 \mathrm{x}$ & Navaho x ORUS 1122-1 \\
\hline ORUS 1393-3 & 261.6 & $5 \mathrm{x}$ & Navaho x ORUS 1122-1 \\
\hline ORUS 1393-4 & 265.0 & $5 \mathrm{x}$ & Navaho $x$ ORUS $1122-1$ \\
\hline ORUS 1394-1 & 266.3 & $5 \mathrm{x}$ & Navaho x Black Butte \\
\hline ORUS 1395-1 & 317.0 & $7 \mathrm{x}$ & Navaho x Kotata \\
\hline ORUS 1395-2 & 304.0 & $6 x$ & Navaho $x$ Kotata \\
\hline ORUS 1397-1 & 320.0 & $7 \mathrm{x}$ & Kotata $\times$ Navaho \\
\hline ORUS $1397-2$ & 265.9 & $5 \mathrm{x}$ & Kotata $\times$ Navaho \\
\hline ORUS $1397-3$ & 290.8 & $6 x$ & Kotata $x$ Navaho \\
\hline ORUS 1397-4 & 260.2 & $5 \mathrm{x}$ & Kotata $x$ Navaho \\
\hline ORUS 1397-5 & 302.1 & $6 x$ & Kotata $\times$ Navaho \\
\hline ORUS 1397-6 & 304.5 & $6 x$ & Kotata $\times$ Navaho \\
\hline ORUS $1398-1$ & 316.8 & $7 \mathrm{x}$ & Lincoln Logan x Navaho \\
\hline ORUS $1398-2$ & 260.5 & $5 \mathrm{x}$ & Lincoln Logan x Navaho \\
\hline ORUS $1410-1$ & 211.7 & $4 \mathrm{x}$ & Chester Thornless x Illini Hardy \\
\hline ORUS 1413-1 & 335.7 & $7 \mathrm{x}$ & Marion $x$ Chester Thornless \\
\hline ORUS 1438-1 & 328.8 & $7 \mathrm{x}$ & [Douglass $\times($ LB $\times$ Mono $)] \times$ Walt \\
\hline ORUS $1438-2$ & 405.9 & $9 \mathrm{x}$ & [Douglass $\times($ LB $\times$ Mono $)] \times$ Walt \\
\hline ORUS $1438-5$ & 333.1 & $7 x$ & [Douglass $\times($ LB $\times$ Mono $)] \times$ Walt \\
\hline ORUS 1442-2 & 425.0 & $9 x$ & [Douglass $\times($ LB $\times$ Mono $)] \times$ Rich \\
\hline ORUS $1442-3$ & 415.4 & $9 \mathrm{x}$ & [Douglass $\times($ LB $\times$ Mono $)] \times$ Rich \\
\hline ORUS 1469-1 & 350.9 & $8 \mathrm{x}$ & Ranui x NW 8729-2 \\
\hline ORUS $1508-0$ & 287.0 & $6 x$ & ORUS 913-10 x ORUS 1122-2 \\
\hline ORUS $1532-0$ & 318.1 & $7 \mathrm{x}$ & ORUS 2024 x Siskiyou \\
\hline ORUS $1534-0$ & 323.2 & $7 x$ & ORUS 2024 x Black Butte \\
\hline ORUS $1535-0$ & 349.4 & $7 \mathrm{x}$ & Olallie $\mathrm{x}$ Douglass \\
\hline ORUS $1638-1$ & 278.5 & $6 x$ & ORUS 1122-1 x NW 9059R-3 \\
\hline \multicolumn{4}{|l|}{ Trailing blackberry cultivars } \\
\hline Black Butte & 291.0 & $6 x$ & Siskiyou x ORUS 728-3 \\
\hline Siskiyou & 333.2 & $7 \mathrm{x}$ & ORUS 2027 x ORUS 1826 \\
\hline \multicolumn{4}{|l|}{ Semi-erect blackberry cultivar } \\
\hline Triple Crown & 222.9 & $4 \mathrm{x}$ & C-47 x ARK 545 \\
\hline \multicolumn{4}{|l|}{ Miscellaneous trailing selections } \\
\hline $\mathrm{N}-71$ & 285.0 & $6 x$ & Aurora $x$ Comanche \\
\hline NW 90B1-2 & 288.1 & $6 x$ & ORUS 817R-6 x Siskiyou \\
\hline NZ 9368-5 & 346.6 & $7 \mathrm{x}$ & NZ 8919RDF-7 x NZ 8927RMC.1 \\
\hline NZ 9373-1 & 336.7 & $7 \mathrm{x}$ & NZ 8927RMC-4 x NZ 8956CC-10 \\
\hline Mac. L.L. San Juan & 383.6 & $8 \mathrm{x}$ & B. Douglass selection of $R$. ursinus \\
\hline Mono x LB & 355.3 & $8 \mathrm{x}$ & B. Douglass selection \\
\hline \multicolumn{4}{|c|}{ Species and cultivars compared to try to ascertain identity of 96050} \\
\hline $96050\left(\right.$ CRUB 1917) ${ }^{\mathrm{y}}$ & 196.0 & $4 \mathrm{x}$ & $\begin{array}{l}\text { Collected as } R \text {. crataegifolius in } \mathrm{NE} \\
\text { China, probably } R \text {. parvifolius }\end{array}$ \\
\hline R. crataegifolius $(96064)^{\mathrm{y}}$ & 76.0 & $2 \mathrm{x}$ & R. crataegifolius from NE China \\
\hline R. crataegifolius $(96068)^{\mathrm{y}}$ & 78.7 & $2 \mathrm{x}$ & R. crataegifolius from NE China \\
\hline Jokgal & 65.3 & $2 \mathrm{x}$ & R. crataegifolius cultivar \\
\hline R. crataegifolius Bunge & 87.3 & $2 \mathrm{x}$ & Unknown \\
\hline Jingu Juegal & 75.0 & $2 \mathrm{x}$ & R. crataegifolius cultivar \\
\hline
\end{tabular}

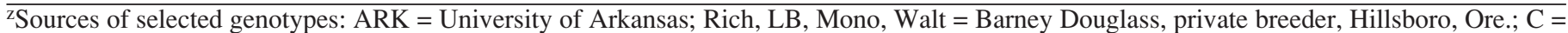
USDA-ARS, Carbondale, Ill.; NW = OSU-NWREC, Aurora, Ore.; NZ, N = HortResearch Inc., New Zealand; ORUS = USDA-ARS, Corvallis, Ore.; A new selection numbering system that included a "-" followed by a number was phased in in the late 1970s. Therefore, selection numbers such as ORUS 1122 and ORUS 1122-1 are different genotypes.

yThompson et al., 1996. 
Table 4. Nuclear DNA content of 21 diploid Rubus species from five subgenera by flow cytometry measurement of fluorescence intensity of propidium iodide-stained nuclei.

\begin{tabular}{|c|c|c|c|c|}
\hline \multirow[b]{2}{*}{ Genotype } & \multirow[b]{2}{*}{ Subgenus } & \multirow{2}{*}{$\begin{array}{c}\text { Reported } \\
\text { ploidy }^{z}\end{array}$} & \multicolumn{2}{|c|}{ 2C Nuclear DNA (pg) } \\
\hline & & & $\operatorname{Mean}^{y}$ & SD \\
\hline Rubus parviflorus $\mathrm{L}$. & Anaplobatus & $2 \mathrm{x}$ & 0.54 & 0.04 \\
\hline Mean & Anaplobatus & & $0.59 \mathrm{ab}$ & 0.08 \\
\hline R. nivalis Douglas ex Hook. & Chamaebatus & $2 \mathrm{x}$ & 0.56 & 0.06 \\
\hline Mean & Chamaebatus & $2 \mathrm{x}$ & $0.56 \mathrm{a}$ & 0.06 \\
\hline R. illecebrosus Focke & Idaeobatus & $2 \mathrm{x}$ & 0.47 & 0.03 \\
\hline R. crataegifolius Bunge & Idaeobatus & $2 \mathrm{x}$ & 0.49 & 0.04 \\
\hline R. leucodermis Doug ex Torrey \& Gray & Idaeobatus & $2 \mathrm{x}$ & 0.51 & 0.03 \\
\hline R. simplex Focke & Idaeobatus & $2 \mathrm{x}$ & 0.52 & 0.04 \\
\hline R. parvifolius $\mathrm{L}$. & Idaeobatus & $2 \mathrm{x}$ & 0.53 & 0.05 \\
\hline R. innominatus $\mathrm{S}$. Moore & Idaeobatus & $2 \mathrm{x}$ & 0.54 & 0.05 \\
\hline R. occidentalis L. & Idaeobatus & $2 \mathrm{x}$ & 0.60 & 0.06 \\
\hline R. lasiostylus Focke & Idaeobatus & $2 \mathrm{x}$ & 0.62 & 0.08 \\
\hline R. ellipticus Sm. & Idaeobatus & $2 \mathrm{x}$ & 0.69 & 0.07 \\
\hline Mean & Idaeobatus & $2 \mathrm{x}$ & $0.67 \mathrm{~b}$ & 0.11 \\
\hline R. hispidus L. & Rubus & $2 \mathrm{x}$ & 0.59 & 0.09 \\
\hline R. canadensis L. & Rubus & $2 \mathrm{x}$ & 0.59 & 0.10 \\
\hline R. trivialis Michx. & Rubus & $2 \mathrm{x}$ & 0.71 & 0.11 \\
\hline R. canescens DC. & Rubus & $2 \mathrm{x}$ & 0.73 & 0.08 \\
\hline R. sanctus Schreb. & Rubus & $2 \mathrm{x}$ & 0.75 & 0.11 \\
\hline Mean & Idaeobatus & $2 \mathrm{x}$ & $0.56 \mathrm{a}$ & 0.08 \\
\hline
\end{tabular}

${ }^{\mathrm{z}}$ As reported by Thompson (1995a, 1995b, 1997).

${ }^{\mathrm{y}_{\text {LSD }}}$ subgenera $=0.11$. Means of subgenera with the same letter are not significantly different at $P \leq 0.05$.

a razor blade to $<0.5 \mathrm{~mm}$ in size to homogenize the tissues and release the nuclei. Leaf tissue was used because it was usually available year round. The nuclei suspension was then filtered to remove debris that might block the flow cell with a filter system that is composed of a $10-\mathrm{mL}$ syringe and $30-\mu \mathrm{m}$ nylon mesh. The nuclei suspension was filtered into a $1.5-\mathrm{mL}$ centrifuge tube and DNAase-free RNase (Sigma R-4642, 0.06\% v/v) was added to avoid binding of the propidium iodide (PI) to RNA. The tube was placed in a water bath at $37^{\circ} \mathrm{C}$ for $15 \mathrm{~min}$ to digest the RNA. The nuclei in the centrifuge tube were then stained by adding 5 $\mathrm{mg} \cdot \mathrm{mL}^{-1}$ PI stock solution to a final PI concentration of 250 $\mu \mathrm{g} \cdot \mathrm{mL}^{-1}$. This mixture was held in a water bath at $37^{\circ} \mathrm{C}$ for 15 min. Since PI is sensitive to light and heat, the PI stock solution was prepared in advance, covered with aluminum foil and kept in a refrigerator.

To calculate nuclear DNA content, rainbow trout(Oncorhynchus mykiss Walbaum) red blood cells (TRBC) [source: Oregon Department of Fish and Wildlife-Corvallis Research Laboratory] were used as a standard. The TRBC stained with the same PI concentration as the Rubus nuclei and were added to the nuclei suspension to be run in the flow cytometer at a concentration of $10^{5} \mathrm{TRBC}$ nuclei/ $\mathrm{mL}$.

Flow CYTOMETRY. A flow cytometer(EPICS XL-MCL; Coulter Corporation, Miami, Fla.) was used for the nuclei suspension analysis. The laser-emission wavelength was adjusted to $488 \mathrm{~nm}$. Each sample consisted of $300 \mu \mathrm{L}$ of nuclei suspension, and analysis was conducted at a data rate of 100 to 150 nuclei per second. A minimum of 5,000 total events were acquired. The samples were run in a darkened lab to prevent PI degradation. The nuclear DNA content per 2C $(\mathrm{C}=$ minimum DNA content per haploid cell of an organism) nucleus was calculated based on the fluorescence of TRBC (5.05 pg/nuclei) (Arumuganathan and Earle, 1991), using the following formula: sample DNA content $=5.05 \times$ sample fluorescence intensity $/ \mathrm{TRBC}$ fluorescence intensity.

To estimate the putative ploidy level of unknown genotypes, we compared the fluorescence of different Rubus genotypes with known ploidy levels (via chromosome counts) and calculated a regression line with a $95 \%$ prediction interval. The inverse prediction (95\%) was made to give the upper and lower limit of fluorescence of all ploidy levels (Ramsey and Schafer, 1997).

\section{Results}

The fluorescence intensity for the group of genotypes with known ploidy levels increased as ploidy level increased (Table 1, Fig. 1). There were significant differences in mean fluorescence between ploidy levels ( $P \leq 0.001)$, with fluorescence highly correlated with ploidy level $\left(r^{2}=0.99, P \leq 0.0001\right)$ (Table 1 and Fig. 1). The fluorescence intensity increased as ploidy level increased (one-sided $P \leq 0.0001, t$ test) for the species in all eight subgenera, although they showed a wider variation in fluorescence intensity than the first group of plant material $\left(r^{2}=0.96, P\right.$ $\leq 0.0001$ ) (Table 2, Fig. 2).

While $R$. ursinus has been split by some taxonomists into a few different species based on ploidy level and geographic distribu- 


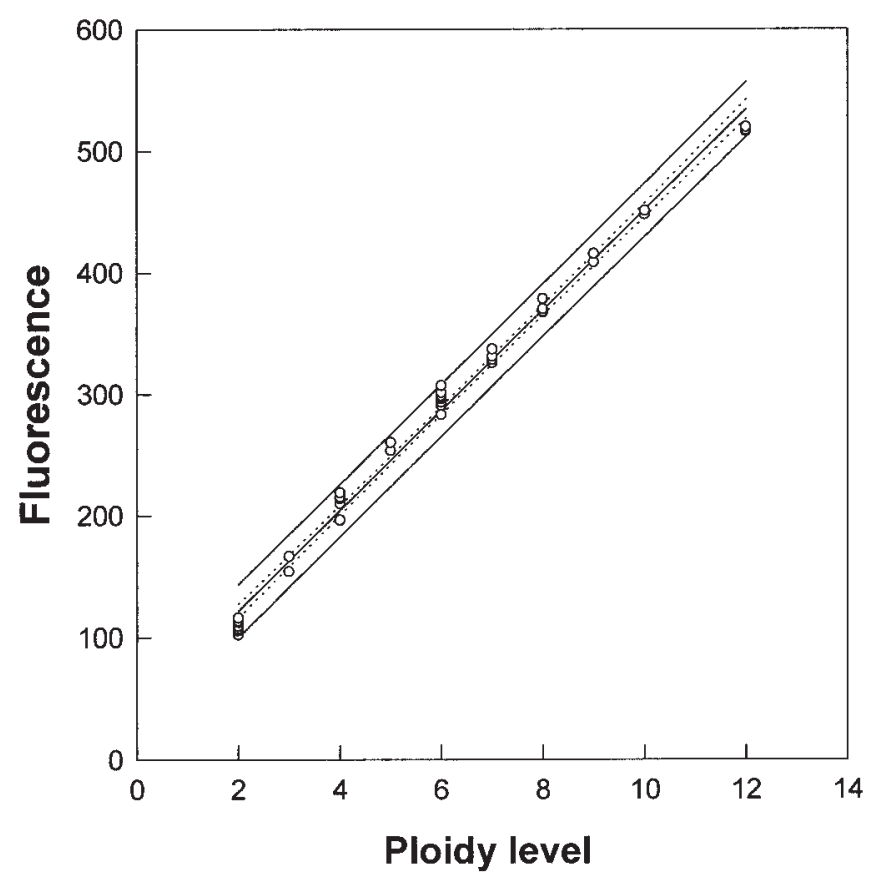

Fig. 1. Fluorescence intensity of propidium iodide-stained nuclear DNA as a function of ploidy level for 40 Rubus genotypes with known ploidy levels (Thompson, 1995a, 1995b). The regression line is highly significant $(P \leq$ $0.0001)$. The inner solid line is the estimated mean fluorescence as a function of the ploidy. The dotted lines are the $95 \%$ confidence interval for the regression line. The two outer solid lines are the upper and lower endpoints of $95 \%$ prediction intervals for the fluorescence at ploidy levels ranging from $2 \mathrm{x}$ to $12 \mathrm{x}$.

tion, we used the classification set forth by Jennings (1988) where he considers these to be ecospecies of one polyploid cenospecies. Using the $95 \%$ prediction interval of fluorescence intensity range, the ploidy level of $110 R$. ursinus genotypes from 42 populations of $R$. ursinus was estimated. Most of the genotypes were $11 \mathrm{x}, 12 \mathrm{x}$ or $13 \mathrm{x}$, but $6 \mathrm{x}, 7 \mathrm{x}, 8 \mathrm{x}, 9 \mathrm{x}$, and 10x genotypes were also represented (Fig. 3). Many samples collected from the same site had different ploidy levels. Our attempts to use microscopy to confirm the $13 x$ genotypes were not successful.

Using the $95 \%$ prediction interval, the ploidy levels of cultivars and selections in our breeding program were estimated (Table 3).

Idaeobatus and Chamaebatus had significantly lower DNA content than those of Rubus and Cylactis (Table 4). In subgenus Rubus, diploid genotypes, $R$. hispidus L. and $R$. canadensis L. had the lowest DNA content and $R$. sanctus Schreb had the highest DNA content, 0.59 and $0.75 \mathrm{pg}$, respectively (Table 4). Idaeobatus had greater variation in DNA content among diploid species than the Rubus subgenus, with the highest content being from $R$. ellipticus Smith $(0.69 \mathrm{pg})$ and lowest content from $R$. illecebrosus Focke (0.47 pg) (Table 4).

\section{Discussion}

Unreduced gametes are frequently produced in Rubus, leading to progeny with varying chromosome numbers, which makes predicting the ploidy level of the progeny difficult. Fertility of the progeny is often correlated with its ploidy level. By using the protocol developed in this research, ploidy level can be determined easily and reliably and problematic progenies can be identified, saving time and resources. In an effort to incorporate valuable traits from materials from materials from outside our breeding program, high ploid blackberries are crossed with

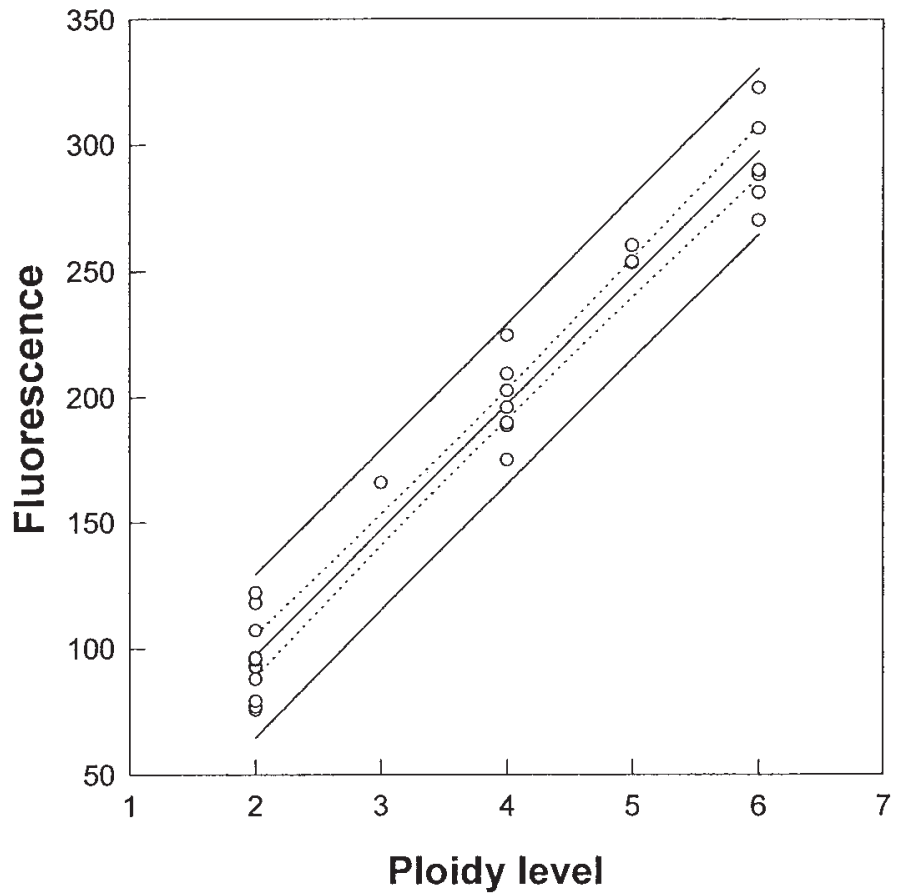

Fig. 2. Fluorescence intensity of propidium iodide-stained nuclear DNA as a function of ploidy level for 30 genotypes representing eight Rubus subgenera. The regression line is highly significant $(P \leq 0.0001)$. The inner solid line is the estimated mean fluorescence as a function of the ploidy. The dotted lines are the $95 \%$ confidence interval for the regression line. The two outer solid lines are the upper and lower endpoints of $95 \%$ prediction intervals for the fluorescence at ploidy levels ranging from $2 \mathrm{x}$ to $6 \mathrm{x}$.

tetraploid eastern blackberries. We can now use flow cytometry to determine if offspring from these crosses true hybrids. For example, ORUS 1395-1 and ORUS 1395-2 have the same 4x maternal and $7 x$ paternal parents, and are $6 x$ and $7 x$, respectively, confirming that our selections were from a successful hybridization.

Most of the genotypes tested gave the expected results, but there was some deviation from the regression line. Variation from the flow cytometer and in sample preparation can contribute to the variation in the results. Theoretically, when the ploidy level is zero, there should be no fluorescence output. However, with our regression equation (fluorescence $=39.26+41.24 \times$ Ploidy), the $\mathrm{y}$-intercept was 39.26 when the ploidy was zero. This is most likely due to other fluorescent materials, such as residual PI, in solution as well as chloroplasts and mitochondrial DNA and ribosomal RNA, which might not have been destroyed completely with the current protocol.

Consistent leaf sampling is critical for obtaining consistent results. Surprisingly large variation in nuclear DNA content have been reported to occur in response to factors such as stress (Bassi, 1990; Price, 1991), so healthy leaves are required. We also found that the freshness of the leaves directly contributed to the successful isolation of intact nuclei (data not shown). New leaves from young canes are ideal for nuclei suspension preparation, because older leaves can produce fewer intact nuclei and these nuclei fluoresce less.

Rubus ursinus is widely distributed in the Pacific Northwest and $6 \mathrm{x}, 8 \mathrm{x}, 9 \mathrm{x}, 10 \mathrm{x}, 11 \mathrm{x}$, and 12x have been reported throughout California, Oregon, Washington, and British Columbia, with $12 \mathrm{x}$ genotypes most common (Brown, 1943). No 7x, 9x, 10x, and 11x genotypes had been previously reported in Oregon, Washington, and British Columbia (Brown, 1943) and no 13x has ever been 


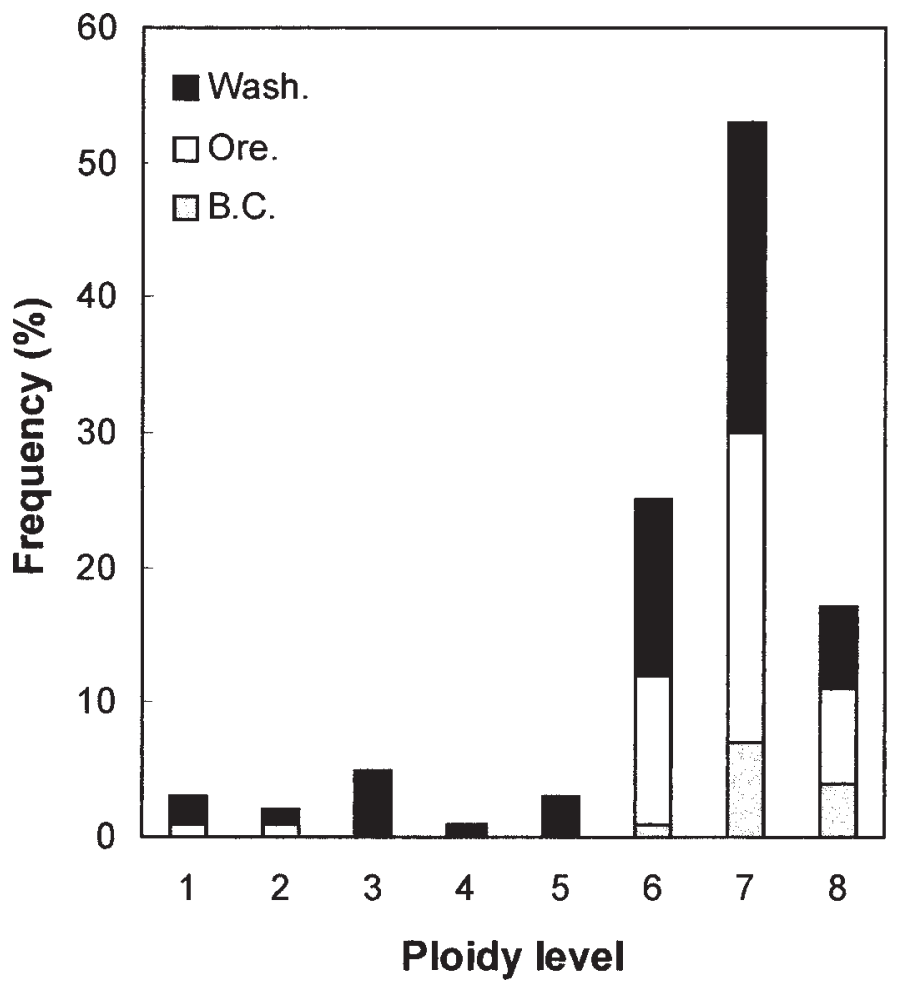

Fig. 3. Distribution of ploidy level as determined by flow cytometry for 110 Rubus ursinus genotypes collected from 42 populations from the Pacific Northwest. Actual locations of collections available upon request.

reported. In our material, we found plants with PI fluorescence suggesting individuals with $13 x$ ploidy. While attempted, these could not be confirmed with chromosome counts. The occurrence of $8 \mathrm{x} R$. ursinus (2 genotypes) in northern Washington was surprising as the $8 \mathrm{x}$ forms have been hypothesized to only occur in California and southern Oregon (Brown, 1943). Ploidy level, $8 x$ vs. 12x, and geographical location were used by Brown (1943) to discriminate $R$. ursinus from $R$. macropetalus. Our results suggest that the $8 \mathrm{x}$ types can be found throughout a much broader range than previously suggested. The range of ploidy levels that we determined in $R$. ursinus also suggests that this species exists at several ploidy levels and thus, for $R$. ursinus, ploidy level is probably not a valid criteria for separating these various forms into different species.

The most common mode of polyploidization is through the formation and sexual functioning of nonreduced gametes, followed by union with reduced gametes. An increase in chromosome numbers can occur in the first or later hybrid generations. To directly produce polyploids by the fertilization of nonreduced gametes from both parents is very rare (deWet, 1980). Therefore, although $13 x$ genotypes had not been reported, they are possible. A $13 x$ can be produced through crosses with nonreduced gametes, such as $10 x$ by $8 x, 12 x$ by $7 x, 8 x$ by $9 x, 6 x$ by $10 x$, and even in rare cases, $6 \mathrm{x}$ by $7 \mathrm{x}$ (nonreduced gametes are produced from both parents). Also, genotypes with the same chromosome number but different nuclear DNA content may be produced through somatic doubling or the sexual functioning of nonreduced gametes in polyploids developed from diploid species with variable nuclear DNA content. The biggest difference in DNA content in our study was between $R$. sanctus $(0.75 \mathrm{pg})$ and $R$. illecebrosus $(0.47 \mathrm{pg})$, a difference of $0.28 \mathrm{pg}$. So, in theory the difference between two $12 \mathrm{x}$ genotypes could be as large as $1.68 \mathrm{pg}(0.28 \mathrm{pg}$ x 6), which equals the DNA from 4.48 to 7.15 sets of chromosomes if the polyploids are formed by spontaneous somatic doubling. In other words, a 12x genotype could have the same nuclear DNA content (fluorescence) of as a genotype that is $>8 \mathrm{x}$ in ploidy. The situation leading to such large differences is not likely because somatic doubling is extremely rare. However, genome variation can still exist among genotypes with the same chromosome number, especially in higher polyploids. Actually, the higher the ploidy level the larger the difference among the genotypes of the same ploidy. Therefore, the predicted $13 x$ genotypes may actually be $12 \mathrm{x}$ with a larger nuclear DNA content that accumulated during evolution from a $2 x$ species with a larger genome. Obviously, research needs to be done to study the cytological characters of representatives of populations of $R$. ursinus.

Due to abnormal meiosis that leads to nonreduced gametes and uneven chromosome segregation in odd-ploid plants, the phenomenon of different ploidy levels existing in the different selections from the same cross was often evident, e.g. ORUS 1112-1 (6x) and ORUS 1112-2 (7x). Selections ORUS 1398-1 ('Lincoln Logan' x 'Navaho') and ORUS 1413-1 ('Marion' $x$ 'Chester Thornless') were 7x instead of the expected 5x and ORUS $1395-1$ is $7 x$. The ploidies of these selections are apparently the result of the nonreduced gamete formation in the $4 x$ parent, 'Navaho' or 'Chester Thornless'.

Using laser flow cytometry of isolated nuclei stained with PI provides an opportunity for rapid determination of nuclear DNA content of diploid Rubus species. The overall genome size of Rubus, as determined here from 21 species in five subgenera, was $0.30 \pm 0.05 \mathrm{pg}$. The results of this research confirm the existence of significant DNA content variation among diploid Rubus species and subgenera, from the smallest, $0.47 \mathrm{pg}$ from $R$. illecebrosus, to the largest, $0.75 \mathrm{pg}$ from $R$. sanctus. However, this is not as much variation as in Helianthus, which has a 4-fold variation among diploid species (Sims and Price, 1985). Analyzing more than one diploid species within the Chamaebatus and Cylactis would give greater strength to these results. Chamaebatus has only one diploid species and there was only one diploid Cylactis species available.

Nuclear DNA content of diploid genotypes from five subgenera were compared (Table 4). Rubus and Cylactis had high DNA content while Idaeobatus and Chamaebatus had low levels, with Anaplobatus as intermediate. Within the Rubus subgenus, there was no significant variation among the five species tested (Table 4). Whereas, Idaeobatus had significant variation among the 12 species tested (Table 4). Several processes could account for this variation. Selection and accumulation of deletions or duplications may explain the variation in nuclear DNA content, which may result in the interspecific DNA differences (Price, 1976). Part of the variation in nuclear DNA content could result from highly reiterate (redundant) sequences of DNA in the genome. Environmental and genomic stress may have activated the amplification and deletion of DNA sequences (Bennett and Leitch, 1995).

When trying to differentiate aneuploids in our experiments, we had only four aneuploids available with known ploidy. They were a 'Tayberry' seedling (RUB 227, 2n = 6x $+2=44$ ), 'Carolina' (RUB 102, 2n=7x + 4 =53), 'Aurora' (RUB 101 and RUB 134, 2n = 8x + 2=58), and 'Santiam' (RUB 79, 2n = 6x + 5 = 47). The fluorescence from 'Aurora' and the 'Tayberry' seedling was not consistently higher than that from other $8 \mathrm{x}$ and 6x genotypes, respectively. This could be due to two reasons: 1) the cytological composition is different between 'Aurora' and 
other 8x genotypes and between the 'Tayberry' seedling and other $6 \mathrm{x}$ genotypes, and the total number of chromosome base pairs from 'Aurora' or the 'Tayberry' seedling is not more than that of other $8 \mathrm{x}$ ( or 6x) genotypes, or 2) the 'Aurora' or 'Tayberry' seedling's genome is bigger than other $8 \mathrm{x}$ (or $6 \mathrm{x}$ ) genotypes' genomes but our protocol is not sensitive enough to detect the increase of fluorescence produced by two chromosomes. For 'Santiam' and 'Carolina', their fluorescence was higher than other $8 x$ species, but couldn't be separated from the 9x genotypes. There have not been any reports on the cytological or molecular composition of Rubus genome that would have been useful for detecting aneuploids.

Nuclear DNA flow cytometry can be used to determine ploidy level and nuclear DNA content in Rubus. The protocol we developed to differentiate ploidy level in Rubus genotypes is effective in differentiating genotypes differing by $1 x$. It can be used on cultivars and wild species throughout the Rubus genera and provides a more efficient technique than microscopic chromosome counting. Flow cytometry provides the opportunity to quickly determine genome size of Rubus genotypes, which is an important parameter for many aspects of studies at the molecular level.

\section{Literature Cited}

Anderson, A.K. and C.E. Finn. 1996. Geographical influences on morphological variation in Rubus ursinus subsp. macropetalus. HortScience 31:609 (abstr.).

Arumuganathan, K. and E.D. Earle. 1991. Estimation of nuclear DNA content of plants by flow cytometry. Plant Mol. Biol. Rpt. 9:229-241.

Bassi, P. 1990. Quantitative variations of nuclear DNA during plant development. A critical approach. Biol. Rev. 65:185-225.

Bennett, M.D. and I.J. Leitch. 1995. Nuclear DNA amounts in angiosperms. Ann. Bot. 76:113-176.

Brown, S.W. 1943. The origin and nature of variability in the Pacific Coast blackberries (Rubus ursinus Cham. \& Schlecht. and R. lemurum sp. nov.). Amer. J. Bot. 30:686-697.

deWet, J.M.J. 1980. Origins of polyploids, p. 3-16. In: W.H. Lewis (ed.).
Polyploidy_Logical relevance. Plenum Press, New York.

Finn, C.E. and R.R. Martin. 1996. Distribution of tobacco streak, tomato ringspot, and raspberry bushy dwarf viruses in Rubus ursinus and $R$. leucodermis collected from the Pacific Northwest. Plant Dis. 80:769772.

Finn, C.E., B.C. Strik, and F.J. Lawrence. 1997. Marion trailing blackberry. Fruit Var. J. 51:130-132.

Galbraith, D.W., K.R. Harkins, J.M. Mardox, N.M. Ayres, D.P. Sharma, and E. Firoozabady. 1983. Rapid flow cytometric analysis of the cell cycle in intact plant tissues. Science 220:1049-1051.

Jennings. D.L. 1988. Blackberries, p. 39-58. In: Raspberries and blackberries: Their breeding, disease and growth. Academic Press, London.

Lawrence, F.J. 1986. A review of interspecific hybridization in Rubus. HortScience 21:58-61.

Meng, R. and C.E. Finn. 1999. Using flow cytometry to determine ploidy level in Rubus. Acta Hort. 505:223-227.

Moore, J.N. 1984. Blackberry breeding. HortScience 19:183-185.

Price, H.J. 1991. Genome stress, genome size and plant adaptation, p. 277-287. Commentary to Chapter 9 (B). In: G.E. Taylor, Jr., L.F. Pitelka, and M.T. Clegg (eds.). Ecological genetics and air pollution. Springer-Verlag, New York.

Price, H.J. 1976. Evolution of DNA content in higher plants. Bot. Rev. 42:27-52.

Ramsey, F.L. and D.W. Schafer. 1997. The statistical sleuth: A course in methods of data analysis. Duxbury Press, Belmont, Calif.

Sims, L.E. and H.J. Price. 1985. Nuclear DNA content variation in Helianthus (Asteraceae). Amer. J. Bot. 72:1213-1219.

Thompson, M.M. 1995a. Chromosome numbers of Rubus cultivars at the National Clonal Germplasm Repository. HortScience 30:14531456.

Thompson, M.M. 1995b. Chromosome numbers of Rubus species at the National Clonal Germplasm Repository. HortScience 30:1447-1452.

Thompson, M.M., J.D. Postman, and C.E. Finn. 1996. Exploration for Rubus, Vaccinium, Ribes and Fragaria germplasm in northeast China. Rpt. USDA Plant Exchange Office, Beltsville, Md.

Thompson, M.M. 1997. Survey of chromosome number in Rubus (Rosaceae: Rosoideae). Ann. Mo. Bot. Garden 84:129-165.

Waldo, G.F. 1950. Breeding blackberries. Ore. State College Agr. Expt. Sta. Bul. 475. 